\title{
2. RUCHLIWOŚĆ MIESZKANIOWA LUDNOŚCI W MIASTACH NA POCZĄTKU XXI W. PRZYPADEK TORUnia ${ }^{1}$
}

\subsection{WPROWADZENIE}

Koniec XX wieku w Polsce to okres intensywnych zmian zachodzących na płaszczyźnie politycznej, gospodarczej i społecznej. Intensywne przemiany objęły swym zasięgiem również przestrzeń miejską, która zdaniem B. Jałowieckiego jest stawką w swoistej ,grze o miasto”. Aktorami w tej grze są nowe podmioty dążące do osiągnięcia korzyści przestrzennych, tj. samorządy, przedsiębiorcy, jak również osoby prywatne dysponujące środkami finansowymi na konsumpcję indywidualną (Jałowiecki 1992). Jak wskazuje autor, mimo pewnych prawnych ograniczeń, w tej nietypowej grze panują dość swobodne reguły, a decydujące znaczenie ma pieniądz. Uwolnienie rynku mieszkaniowego, powrót znaczenia renty gruntowej oraz innych mechanizmów rynkowych determinujących proces szybkiego różnicowania majątkowego mieszkańców nasiliły ruchliwość mieszkaniową najbardziej mobilnych ekonomicznie grup społecznych, dla których miejsce zamieszkania staje się świadomym wyborem².

\footnotetext{
${ }^{1}$ Praca powstała przy współfinansowaniu MNiSW w ramach grantu promotorskiego nr NN 306340237.

${ }^{2}$ Istnieje przekonanie, iż w warunkach miasta socjalistycznego egalitarne zasady przydziału mieszkań oraz panujący reżim komunistyczny pozbawił ludzi możliwości wyboru i sposobu zamieszkania (Basista 1999). Odmienną opinię w tej kwestii wyraża I. Sagan (2000a). Autorka stoi na stanowisku, iż w mieście socjalistycznym, mimo wytrwałych dążeń do homogenizacji przestrzeni miejskiej, hierarchia miejsc nie została zatarta. Miejsca, choć pozbawione wartości rynkowej, zachowały wartość i rangę społeczną. Nadal istniały najbardziej pożądane lokalizacje oraz te, które były ,złym
} 
Dążenie do zajęcia pożądanej lokalizacji w mieście sprawia, że dominujące w miastach socjalistycznych mozaikowe struktury zaczynają porządkować się zgodnie z prawami rynku, określającymi atrakcyjność poszczególnych obszarów miejskich (Sagan 2000b). Zaznaczyć jednak należy, iż hierarchia atrakcyjności mieszkaniowej określonych fragmentów przestrzeni miasta jest wyrazem nie tylko obiektywnej oceny szeroko pojętych warunków mieszkaniowych, lecz również procesu ich percepcji i waloryzacji. Ponadto istotne znaczenie $\mathrm{w}$ kreowaniu głównych kierunków przemieszczeń posiada fakt ,zakorzenienia" w określonych fragmentach przestrzeni miejskiej. W wielu przypadkach determinuje on poszukiwanie nowego lokalu mieszkaniowego w bliskiej odległości od dotychczasowego miejsca zamieszkania (Radwańska 2011).

Głównym celem niniejszego opracowania jest charakterystyka migracji wewnątrzmiejskich dokonujących się w Toruniu w latach 2003-2005. Cel ten realizowany jest poprzez: określenie skali zjawiska, analizę cech demograficzno-społecznych migrantów oraz rozpoznanie ogólnych prawidłowości przemieszczeń. Badania przeprowadzono w oparciu o niepublikowane dane Urzędu Miasta w Toruniu w zakresie zmian stałego miejsca pobytu mieszkańców miasta.

\subsection{MIGRACJE WEWNĄTRZMIEJSKIE JAKO PRZEDMIOT BADAŃ NAUKOWYCH}

W dorobku polskiej geografii studia poświęcone przemieszczeniom ludności między różnymi jednostkami administracyjnymi zajmują ważne miejsce. Dominują opracowania wybranych zagadnień przestrzennych ludności z punktu widzenia typu i kierunków migracji, struktury migrantów, zróżnicowań przestrzennych oraz procesów uprzemysłowienia i urbanizacji (Gawryszewski 1989). Zostały one dość dobrze rozpoznane i opisane, czego wyrazem są liczne opracowania zarówno o charakterze monografii, jak i artykułów naukowych (Gawryszewski 1989; Szajnowska-Wysocka 1999; Więcław-Michniewska 2006).

Szczególny rodzaj zachowań przestrzennych ludności stanowią migracje wewnątrzmiejskie rozumiane jako przemieszczenia w obrębie tej samej jednostki administracyjnej - miasta, prowadzące do zmiany stałego miejsca zamieszkania. W literaturze przedmiotu są one nazywane ruchliwością mieszkaniową lub migracjami rezydencjalnymi, ponieważ przemieszczenia te są związane przeważnie z uzyskaniem własnego mieszkania lub dążeniem do poprawy warunków mieszkaniowych i bytowych (Clark 1981; Kozieł 1984, 1989; Węcławowicz 2007). Wiedza na ten temat jest wciąż niezadowalająca. Główną przyczyną tego stanu rzeczy jest brak odpowiednich danych $\mathrm{w}$ instytucjach

adresem". Zajmowanie szczególnie prestiżowych miejsc, za które uchodziły przede wszystkim centralne rejony miasta, odbywało się na bazie stosunków politycznych. Kwestie ekonomiczne nie miały w tym względzie większego znaczenia (ibid.) 
statystycznych oraz trudności w pozyskiwaniu informacji przez badaczy. Publikowane przez Główny Urząd Statystyczny informacje są niewystarczające. Wynika to z przyjętej przez tę instytucję definicji pojęcia migracji, według której ,za migracje przyjmuje się taką zmianę miejsca zamieszkania, z którą jest związane przekroczenie granicy jednostki administracyjnej podstawowego rzędu: miasta lub gminy". Konsekwencją tego jest brak rejestracji ruchów migracyjnych w obrębie tego samego miasta $\mathrm{z}$ wyjątkiem kilku największych, przy czym należy pamiętać, iż rejestrowane są jedynie migracje międzydzielnicowe $\mathrm{z}$ pominięciem ruchów w obrębie tej samej dzielnicy. W takiej sytuacji podstawą analizy procesu migracji w mikroskali mogą być informacje pochodzące $z$ ewidencji bieżącej, rejestru PESEL lub badań ankietowych. Duża czasochłonność, pracochłonność, czy też koszt uzyskania informacji i ograniczenia związane z obowiązującą od 1997 r. Ustawą o ochronie danych osobowych skutecznie ograniczają liczbę podjętych prac w tym zakresie. Istniejące opracowania na temat migracji wewnątrzmiejskich dotyczą kilku największych miast w Polsce, tj. Warszawy (np. Potrykowska 1996, 2002; Potrykowska, Śleszyński 1999), Łodzi (np. Kaczmarek, Liszewski 1991; Michalski, Szafrańska 2000), Krakowa (np. Zborowski 1996, 2005; Więcław-Michniewska 2006), Wrocławia (np. Kozieł 1984, 1987, 1989, 1996, 1998) czy Poznania (Marcinowicz 2000).

\subsection{PRZESTRZENNE PRAWIDLOWOŚCI MIGRACJI WEWNĄTRZMIEJSKICH}

Migracje wewnątrzmiejskie cechują określone prawidłowości przestrzenne. Najczęściej wykrywaną regularnością jest przemieszczanie się od centrum miasta w kierunku przedmieść i obszarów podmiejskich. Zjawisko to związane jest $\mathrm{z}$ intensywnym rozwojem usług $\mathrm{w}$ centralnych rejonach miasta i powstaniem dzielnic typu „city”. Wypieranie funkcji mieszkaniowej z centralnych rejonów wielkich miast obserwuje się od początku XX w. w wysoko rozwiniętych i silnie zurbanizowanych państwach europejskich oraz miastach amerykańskich (Pritchard 1976; Kozieł 1989; Maik 1997; Słodczyk 2003). Proces ten jest następstwem przede wszystkim wzrostu cen gruntów. Funkcja rezydencjalna nie jest w stanie konkurować o teren $\mathrm{z}$ usługami i handlem. W centralnych rejonach miast powstają jedynie budynki mieszkaniowe o wysokim standardzie przeznaczone dla najbogatszej części społeczeństwa. Luksusowe apartamenty, najczęściej w wieżowcach, w wielu przypadkach stanowią dodatkowe miejsce zamieszkania ich właścicieli. Osoby te często posiadają również domy na przedmieściach. Odpływ bogatszej ludności z centralnych części miast może doprowadzić do zjawiska określanego mianem kryzysu śródmieścia. Zdaniem J. Słodczyka (2003), degradację centrum miasta obserwuje się szczególnie wyraźnie w dużych, tradycyjnych ośrodkach przemysłowych północnej części Stanów 
Zjednoczonych. Władze lokalne niejednokrotnie podejmują próby doprowadzenia do rewitalizacji centrum miasta. Niemniej jednak skuteczność wdrażanych programów przebudowy i podniesienia atrakcyjności jest ograniczona (Słodczyk 2003). W przypadku miast europejskich proces depopulacji centralnych rejonów miasta nie jest aż tak nasilony. Jednym z działań, których celem jest m.in. zahamowanie niekorzystnych tendencji w zakresie migracji w centralnych rejonach miast są wspomniane już programy rewitalizacyjne. Często wiąże się z nimi proces gentryfikacji, polegający na odnowie zdegradowanych obszarów miasta centralnego poprzez renowację zasobów mieszkaniowych i znacznym podniesieniu standardu mieszkań oraz wymianie dotychczasowej ludności na lepiej sytuowane grupy mieszkańców (klasa średnia) (Jałowiecki, Szczepański 2002). Jak twierdzi L. Sykora (1996) w miastach postsocjalistycznych zjawisko to nie występuje w pełnej skali. Renowacji poddawane są bowiem jedynie pojedyncze bloki czy budynki, nie zaś całe kwartały, jak to ma miejsce w przypadku krajów Europy Zachodniej. Początki tego procesu można obserwować w Warszawie, Łodzi, Krakowie, a w znacznie większym stopniu w Budapeszcie i Pradze (Węcławowicz 2007).

Odpływ pewnych grup ludności $\mathrm{z}$ terenów śródmiejskich może również ograniczyć przekształcenie starych hal przemysłowych i innych pofabrycznych obiektów (magazynów, młynów, warsztatów, wież ciśnień itp.) na tzw. lofty ${ }^{3}$. Lokale $\mathrm{w}$ adaptowanych na cele mieszkaniowe budynkach cechują się oryginalnymi rozwiązaniami przestrzennymi, dużą powierzchnią i specyficzną atmosferą pofabrycznych wnętrz. Możliwość zastosowania awangardowych rozwiązań architektonicznych sprawia, że ten typ mieszkań szczególnie preferują grupy

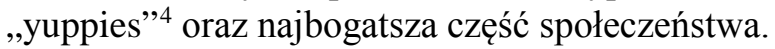

Interesującym aspektem przestrzennym migracji wewnątrzmiejskich jest również ich sektorowy kierunek. Na prawidłowość tę zwrócił uwagę J.S. Adams

\footnotetext{
${ }^{3}$ Moda na nowy, elitarny styl życia przywędrowała ze Stanów Zjednoczonych, gdzie lofty pojawiły się już w latach 60. XX w. Początkowo budynki po opustoszałych zakładach produkcyjnych zajmowali artyści, łącząc w jednym miejscu dom, pracownię oraz galerię. Z czasem pracownie ubogich artystów zaczęli zajmować zamożni ludzie szukający mieszkań o nietypowych wnętrzach. W Polsce pierwsze obiekty tego typu powstały w latach 90. XX w. na warszawskiej Pradze. Do najbardziej znanych należą lofty „U Scheiblera” w Łodzi, mieszkanie w lampiarni na terenie kopalni w Bytomiu oraz lofty de Girarda w Żyrardowie (Stachura 2009).

${ }^{4}$ Termin ten stanowi skrót od young urban professionals, czyli „młodzi miejscy profesjonaliści”. Osoby te cechuje przede wszystkim hiperaktywność, pracoholizm, wysoka świadomość własnej wartości, otwartość na nowe wyzwania zawodowe oraz szczególne upodobanie do nabywania luksusowych towarów i dóbr. W Polsce pokolenie ,japiszonów” pojawiło się wraz z początkiem wielkiej transformacji (Jałowiecki, Szczepański 2002).
} 
(1969) badając ruchliwość mieszkaniową mieszkańców Minneapolis. Uzyskane wyniki dowiodły, że około $1 / 3$ migrujących przemieszczała się w wąskim, 10stopniowym sektorze, który tworzyły odcinki łączące dotychczasowe miejsce zamieszkania z centrum miasta oraz z nowym mieszkaniem (Kozieł 1989). Podjęte badania miały stanowić jedną $\mathrm{z}$ prób połączenia analiz ruchliwości mieszkaniowej oraz map wyobrażeniowych, które istnieją w umysłach migrantów. J.S. Adams sądził, iż obraz poszczególnych części miasta funkcjonujący w umyśle każdej jednostki jest niekompletny i przyjmuje postać klinów. Najbardziej eksponowanym sektorem, o którym wiedza jednostki jest największa jest ten, w którym usytuowane jest miejsce zamieszkania. Wynika to z codziennej wędrówki pomiędzy domem a miejscem pracy (Clark 1981, za: Radwańska 2011). Do podobnych wniosków doszedł J.W. Simmons (1968), który stwierdził, że sektorowość migracji jest $\mathrm{z}$ jednej strony wynikiem przywiązania do miejsca i kontaktów społecznych, z drugiej zaś sektorowej struktury społeczno-ekonomicznej i etnicznej miast amerykańskich (Kozieł 1989). W Polsce badania w tym zakresie prowadził R. Kozieł (1989). Uzyskane przez niego wyniki dowiodły, iż sektorowość migracji występuje zarówno względem centrum miasta - za który badacz przyjął Rynek, jak i miejsca pracy.

Dobra znajomość najbliższego otoczenia miejsca zamieszkania warunkuje jeszcze jedną regularność migracji wewnątrzmiejskich, a mianowicie minimalizację odległości przemieszczeń. W tym przypadku wyjaśnienia należy szukać $\mathrm{w}$ fakcie, iż pomiędzy ludźmi a zamieszkiwanymi fragmentami miasta rodzi się uczuciowa więź określana za Y.-F. Tuan mianem „topofili”. Wieź ta nazywana w literaturze przedmiotu również związkami swojskości daje człowiekowi poczucie bycia u siebie, bycia wśród swoich (Pawłowska 1996), co z kolei wpływa na wysokie poczucie bezpieczeństwa. Fakt ten w wielu przypadkach determinuje poszukiwanie nowego lokalu mieszkaniowego w sąsiedztwie dotychczas zajmowanego miejsca.

O dążności mieszkańców miasta do minimalizacji odległości przemieszczeń wnioskować można na podstawie analizy osób migrujących w obrębie przyjętych do badania tych samych jednostek przestrzennych. Prawidłowość ta potwierdziła się $\mathrm{w}$ analizach prowadzonych w takich miastach, jak Wrocław, gdzie w 1979 r. w obrębie tych samych dzielnic migrowało ok. 45\% osób, zaś w obrębie tych samych osiedli urbanistycznych ok. 17\% (Kozieł 1989, 1996) oraz Łódź, gdzie z kolei w roku 1997 odsetek osób zmieniających miejsce zamieszkania w obrębie tych samych jednostek badawczych wyniósł 19,2\% (Michalski, Szafrańska 2000). 


\subsection{SPOLECZNO-DEMOGRAFICZNE DETERMINANTY MIGRACJI WEWNĄTRZMIEJSKICH I ZWIĄZANE Z TYM ZMIANY W PREFERENCJACH MIGRACYJNYCH}

Migracje dokonujące się w obrębie miast uwarunkowane są wieloma różnorodnymi czynnikami natury demograficznej, społecznej oraz ekonomicznej. Wśród najważniejszych przyczyn zmian miejsca zamieszkania wymienia się zmiany w cyklu życia rodziny oraz związane $\mathrm{z}$ nimi zmiany w potrzebach mieszkaniowych (Jagielski 1977; Kozieł 1989; Strzelecki 1989; Dzieciuchowicz 1995; Zborowski 1996, 2005; Maik 1997; Walmsley, Lewis 1997 i in.).

Pierwszą interpretację migracji wewnątrzmiejskich za pomocą koncepcji cyklu życiowego przedstawił P.H. Rossi (1955) w studium dotyczącym planowanych zmian miejsca zamieszkania 924 rodzin z Filadelfii. Badanie to wykazało, że główną przyczyną przeprowadzki była chęć zaspokojenia potrzeb mieszkaniowych zależnych od zmieniającego się składu rodziny. Gotowość zmiany miejsca zamieszkania najczęściej wyrażały rodziny pełne (małżeństwa $\mathrm{z}$ dziećmi) oraz rodziny niepełne (małżeństwa bez dzieci). Wyższa mobilność wiązała się również z zajmowaniem mieszkania na zasadach lokatorskich, zaś właścicieli mieszkań cechowała mobilność kilkunastokrotnie niższa (Strzelecki 1989; Walmsley, Lewis 1997). Wniosek o związku pomiędzy fazami cyklu rodziny a podatnością na migracje został potwierdzony w późniejszych pracach m.in. J.W. Simmonsa (1968). W ośmiofazowym cyklu życiowym wydzielił on co najmniej pięć potencjalnych zmian miejsca zamieszkania jednostki ludzkiej. Stwierdził też, że ok. 50\% migracji w mieście wynika ze zmiany w cyklu życiowym (Kozieł 1989).

Wpływ wieku mieszkańców miast na skłonność do zmiany miejsca zamieszkania potwierdzają również badania prowadzone we Francji (Donzeau, Pan Ké Shon 2009) oraz Kanadzie (Lord, Joerin, Theriault 2009). W obu przypadkach dowiedziono, że najmniej mobilne są osoby najstarsze, a niechęć do zmiany miejsca zamieszkania wynika na ogół z przyzwyczajenia do zamieszkiwanych miejsc i chęci kontynuacji utartych zachowań. Badania prowadzone w Szwecji dowodzą, że oprócz wieku zmienną obniżającą skłonność do zmiany miejsca zamieszkania jest również poczucie przynależności terytorialnej (Gustafson 2009).

Z polskich prac poświęconych badaniom związków pomiędzy ruchliwością mieszkaniową w miastach a etapami cyklu życiowego na uwagę zasługuje opracowanie R. Kozieła (1989). Autor biorąc pod uwagę fazę cyklu rozwoju rodziny, podzielił badane rodziny i gospodarstwa domowe na 9 typów tj. 1) rozwojowe małżeństwa bez dzieci (wiek małżonki poniżej 40 lat), 2) nierozwojowe małżeństwa bez dzieci (wiek małżonki 40 lat i więcej), 3) małżeństwa z dziećmi w wieku przedszkolnym (najmłodsze dziecko w wieku poniżej 7 lat), 
4) małżeństwa $\mathrm{z}$ dziećmi w wieku szkolnym (najmłodsze dziecko w wieku 7-17 lat), 5) małżeństwa $\mathrm{z}$ dziećmi dorosłymi (najmłodsze dziecko w wieku 18 lat i więcej), 6) matka albo ojciec $\mathrm{z}$ dziećmi, 7) pozostałe rodziny (rodzeństwo, rodziny wielopokoleniowe, babcia lub dziadek z wnukami), 8) osoby samotne w stanie cywilnym wolnym, 9) osoby samotne w stanie cywilnym: żonaty lub zamężna. Największy udział wśród migrujących posiadały osoby samotne (51,4\%). Znaczny był również udział małżeństw z dziećmi $(23,5 \%)$, wśród których dominowały małżeństwa z dziećmi w wieku przedszkolnym (14,5\%). Odsetek rodzin szczątkowych (matka lub ojciec z dziećmi) wyniósł 14,1\%, zaś małżeństw bez dzieci zaledwie $6,7 \%$. Obliczone wartości wskaźników względnej mobilności migracyjnej $\left(\mathrm{W}_{\mathrm{m}}\right)^{5}$ pozwoliły ustalić, iż fazie rozpadu rodziny towarzyszą stosunkowo intensywne migracje wewnątrzmiejskie. Ponadto stwierdzono, że małżeństwa bez dzieci są mniej skłonne do zmiany miejsca zamieszkania niż małżeństwa z dziećmi (Kozieł 1989).

Przechodzenie przez kolejne fazy cyklu życia rodziny implikuje nie tylko okresy wzmożonej bądź osłabionej podatności na zmianę miejsca zamieszkania, lecz również determinuje zmiany $\mathrm{w}$ preferencjach mieszkaniowych. W rozwiniętym społeczeństwie zachodnim typowy cykl życia rodziny obejmuje sześć faz rozwoju, którym odpowiadają określone oczekiwania w zakresie wielkości mieszkania, jego standardu, rodzaju własności oraz lokalizacji (Morgan 1976, za: Zborowski 2005). W pierwszej fazie ,,przeddziecięcej” przeprowadzka jest skutkiem dążności do uzyskania samodzielnego mieszkania. Najbardziej preferowane są lokalizacje $\mathrm{w}$ centrum miasta bądź w jego bezpośrednim sąsiedztwie, co wynika z faktu bliskości miejsc pracy (względnie studiów) oraz oferowanych ułatwień infrastrukturalnych (dobre połączenia komunikacyjne, duża dostępność do miejsc kultury, rozrywki i in.). Wielkość mieszkania i jego standard na tym etapie są mało znaczące. W kolejnej fazie - „rodzenia dzieci” oczekiwania odnośnie nowego miejsca zamieszkania zmieniają się. Wzrost liczby członków rodziny determinuje potrzebę posiadania coraz większego lokalu mieszkaniowego. Konsekwencją tego są 2-3 przeprowadzki, na ogół w obrębie zewnętrznego pierścienia miasta centralnego. Istotnym czynnikiem uwzględnianym przy wyborze nowego miejsca zamieszkania jest również bezpieczne i przyjazne rodzinie $\mathrm{z}$ małymi dziećmi środowisko. W tym okresie zazwyczaj pracę zarobkową wykonuje jedynie ojciec, zaś matka zajmuje się opieką nad

$$
{ }^{5} W_{m}=\frac{\frac{M_{k}}{M}}{\frac{L_{k}}{L}} * 100,
$$

gdzie: $M_{k}$ - migranci kategorii $k, M$ - migranci ogółem, $L_{k}$ - ludność kategorii $k, L-$ ludność ogółem (Kozieł 1989). 
małoletnim potomstwem. Kolejną fazę, tj. „wychowywania dzieci” cechuje wzrost zamożności rodziny będący skutkiem awansu zawodowego ojca, bądź powrotu do pracy matki. Poprawa sytuacji finansowej stwarza możliwość zamieszkania w suburbium. Opuszczenie domu przez dzieci implikuje kolejną zmianę w potrzebach mieszkaniowych. Niemniej jednak, przyzwyczajenie i emocjonalna więź z dotychczasowym miejscem zamieszkania dość skutecznie ogranicza zmianę mieszkania na mniejsze. Prawdopodobieństwo przeprowadzki wzrasta dopiero w sytuacji śmierci jednego ze współmałżonków. Wówczas owdowiała osoba może podjąć decyzję o zamieszkaniu z dorosłym dzieckiem, bądź przeniesieniu się do mniejszego mieszkania (Zborowski 2005).

A. Zborowski (2005) konstatuje, iż przedstawiony model dotyczy dużej części społeczeństwa zachodniego (klasa średnia), lecz nie obejmuje warstw uboższych robotników, w małym stopniu obejmuje też grupy etniczne ludności kolorowej. Jego zdaniem niższe warstwy społeczeństwa preferują inne wartości i style życia, a ograniczone środki finansowe implikują odmienne lokalizacje nowych miejsc zamieszkania. Ponadto zmiany wywołane m.in. rozwojem usług $\mathrm{w}$ postindustrialnej gospodarce, powstaniem informatycznych technologii czy fragmentacją współczesnej przestrzeni miejskiej utrudniają dokładne określenie związku pomiędzy cyklem życia klasy średniej a preferencjami mieszkaniowymi i lokalizacyjnymi (Zborowski 2005). Opinię taką wyrażają również P. Knox i S. Pinch (2000).

W Polsce badania związków pomiędzy zajmowaniem określonych przestrzeni w mieście a etapem cyklu życiowego prowadzili R. Kozieł $(1984,1989)$ oraz A. Zborowski (1996). Analizy przeprowadzone przez R. Kozieła dotyczące zmian miejsca zamieszkania mieszkańców Wrocławia w 1979 r. dowiodły, iż rodziny szczątkowe preferowały strefę centralną, małżeństwa bez dzieci, małżeństwa $\mathrm{z}$ dziećmi $\mathrm{w}$ wieku przedszkolnym oraz szkolnym preferowały strefę przejściową, natomiast rozwojowe małżeństwa bez dzieci i z dziećmi przemieszczały się głównie do strefy peryferyjnej. Tendencje te potwierdziły badania A. Zborowskiego przeprowadzone w Krakowie i kilku wybranych miejscowościach regionu miejskiego w latach 1992 i 1996. Na podstawie ankiet przeprowadzonych z ponad 900 losowo wybranymi rodzinami autor stwierdzil, że w regionie miejskim Krakowa, na który składają się dwie części, tj. miasto centralne oraz strefy peryferyjne (zurbanizowana podmiejska i dojazdów do pracy) występują obszary „uprzywilejowane” przez migrantów znajdujących się w określonej fazie cyklu życia człowieka. Ludność młoda nowe miejsce zamieszkania odnajduje najczęściej w obrębie miasta centralnego, a przyczyną jej migracji jest zazwyczaj fakt zawarcia związku małżeńskiego. Kierunek przemieszczeń rodzin pełnych jest odmienny. Ta grupa migrantów szukając lepszych warunków mieszkaniowych, związanych często $\mathrm{z}$ powiększeniem rodziny, zmienia miejsce zamieszkania $\mathrm{z}$ miasta centralnego na strefę 
peryferyjną. Przeprowadzone analizy dowiodły również, że w im starszej fazie znajduje się rodzina, tym zasięg migracji jest krótszy (Zborowski 1996).

\subsection{CHARAKTERYSTYKA MIGRACJI WEWNĄTRZMIEJSKICH W TORUNIU}

W latach 2003-2005 stałe miejsce zamieszkania w granicach administracyjnych Torunia zmieniło łącznie 18906 mieszkańców. Liczba osób podejmujących decyzję o migracji zmniejszała się. Na początku badanego okresu wynosiła 6 945, zaś w kolejnych latach 6060 (2004 r.) i 5901 osób (2005 r.). Natężenie migracji wewnątrzmiejskich utrzymywało się na dość wysokim poziomie i wyniosło odpowiednio 33,10\%o (2003 r.), 29,05\%o (2004 r.) i 28,35\%o (2005 r.).

Rozkład wieku osób biorących udział w migracjach wewnątrzmiejskich w całym rozpatrywanym okresie lat 2003-2005 wykazuje zgodność z modelowym rozkładem migracji według wieku przedstawionym przez A. Rogersa (1980) (rys. 1). W wykreślonym profilu zaznaczają się trzy wierzchołki oraz trzy najniższe punkty odpowiadające różnym rocznikom. Pierwsza kulminacja obejmuje dzieci w wieku 0-4 lata migrujące wraz ze swoimi rodzicami, zaś pierwszy obniżony punkt profilu przypada na wiek 15-19 lat. Później rozmiary migracji gwałtownie rosną osiągając najwyższą wartość w grupie wieku 25-29 lat. W kolejnych latach obserwuje się spadek liczby podejmowanych zmian miejsca zamieszkania. Sytuacja ta utrzymuje się aż do wieku 44 lat. Ostatnie niewielkie ożywienie ruchów migracyjnych przypada na grupę migrantów w przedziale 45-49 lat, po czym daje się zauważyć znaczne spłaszczenie graficznego obrazu profilu wieku osób biorących udział w migracjach wewnątrzmiejskich. Przesunięcie tzw. „wzniesienia emerytalnego” na wiek 45-49 lat wiązać należy z dążnością do zajęcia optymalnej lokalizacji w mieście i poprawy warunków mieszkaniowych z jednej strony, z drugiej zaś z poprawą sytuacji ekonomicznej większości rodzin na tym etapie cyklu życia. Za najbardziej preferowany typ zabudowy mieszkańców miast uznaje się dom jednorodzinny. Możliwości zamieszkania w budynku jednorodzinnym w pierwszych etapach cyklu życia rodziny są ograniczone, co wynika z czynników ekonomicznych. W późniejszych fazach prawdopodobieństwo poprawy sytuacji finansowej rodziny za sprawą awansu zawodowego wzrasta. Osiągnięcie stabilności finansowej, jak również zmiany w potrzebach mieszkaniowych, zarówno w kwestii standardu mieszkania, jak i jego lokalizacji w przestrzeni miasta sprawiają, iż prawdopodobieństwo przeprowadzki rośnie. Niewielką liczbę migrujących emerytów tłumaczyć można przyzwyczajeniem, sentymentem i wytworzeniem więzi sąsiedzkich, które skutecznie ograniczają podjęcie decyzji o zmianie miejsca zamieszkania w przestrzeni miasta. Prawdopodobieństwo przeprowadzki najstarszych mieszkańców miasta wzrasta dopiero $\mathrm{w}$ sytuacji śmierci 
współmałżonka. Wówczas owdowiała osoba może podjąć decyzję o zamieszkaniu z dorosłym dzieckiem, bądź przeniesieniu się do mniejszego mieszkania.

Wyniki przeprowadzonych badań dowodzą, że kobiety są bardziej mobilne od mężczyzn. Odsetek tej płci w strukturze osób uczestniczących w migracjach wewnątrzmiejskich w latach 2003-2005 wyniósł 52,72\%. Biorąc pod uwagę wiek migrantów można zauważyć istnienie pewnych prawidłowości odpowiadających strukturze płci i wieku ludności naszego kraju, tj. nadwyżkę chłopców nad dziewczynkami wśród migrujących dzieci oraz przewagę migrujących kobiet nad mężczyznami w najstarszych grupach wiekowych. Kulminacja migracji, tak w przypadku kobiet, jak i mężczyzn przypada na przedział wieku 25-29 lat (rys. 2).

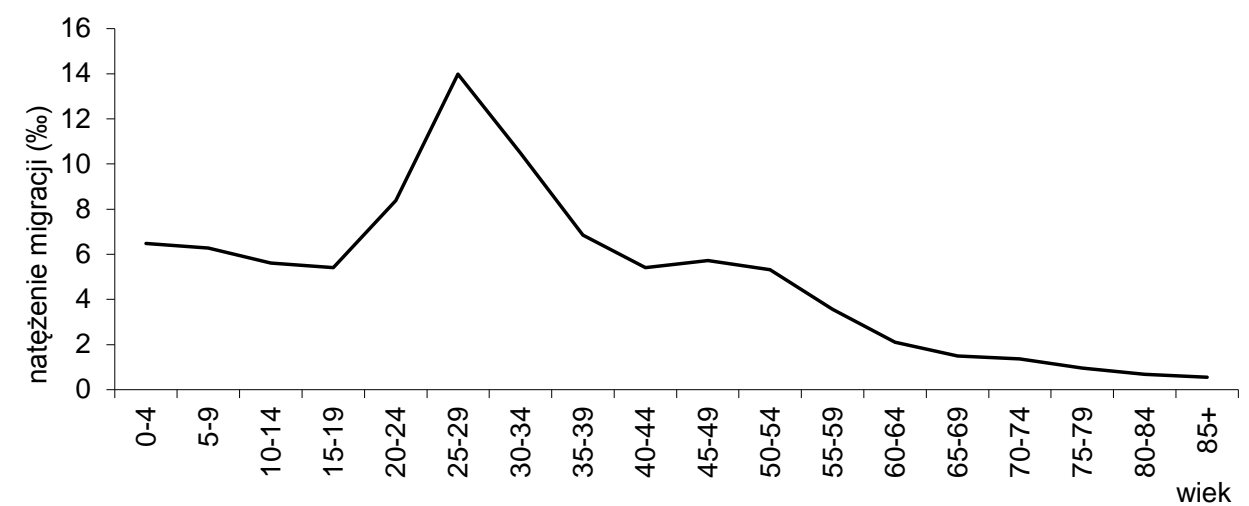

Rys. 1. Rozkład wieku osób, które zmieniły miejsce zamieszkania w Toruniu w latach 2003-2005

Źródło: oprac. własne na podstawie niepublikowanych danych UM w Toruniu

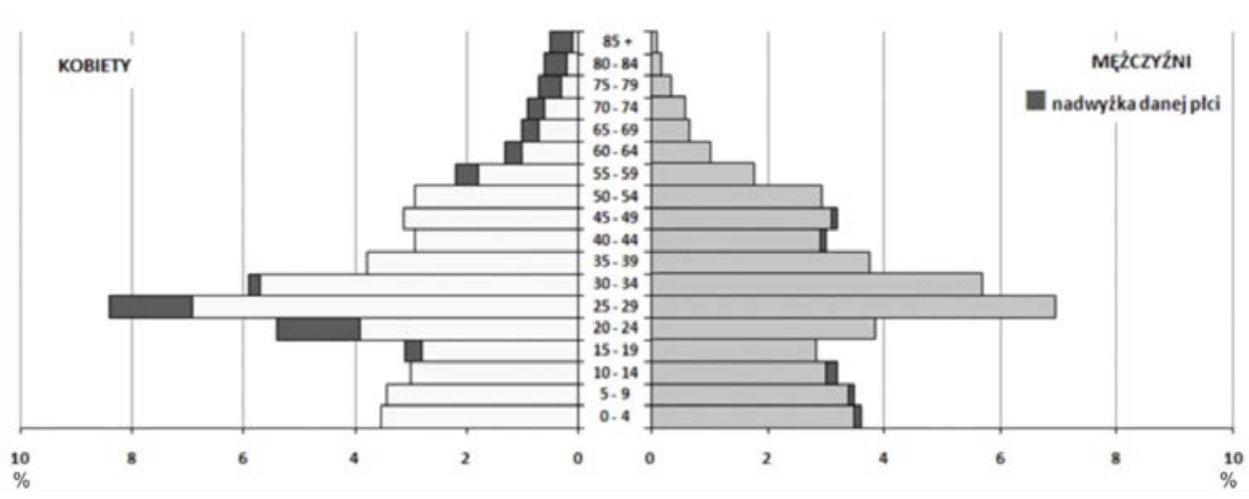

Rys. 2. Struktura płci i wieku osób, które zmieniły miejsce zamieszkania w Toruniu w latach 2003-2005

Źródło: oprac. własne na podstawie niepublikowanych danych UM w Toruniu 
W celu bardziej precyzyjnego określenia ruchliwości migracyjnej osób należących do określonych grup wieku obliczono wskaźniki względnej mobilności migracyjnej. Zaobserwowano dwa okresy wzmożonej ruchliwości mieszkańców Torunia, tj. okres wczesnego dzieciństwa (0-4 lata i 5-9 lat) oraz wczesnego małżeństwa (25-29 lat i 30-34 lata). Barak danych w podziale na całe rodziny lub gospodarstwa domowe uniemożliwia wyciągnięcie jednoznacznych wniosków. Zachowując pewien stopień ostrożności można jednak dwie wskazane grupy traktować łącznie i utożsamiać je jako młode, rozwojowe rodziny. Potwierdza to założenie wpływu określonej fazy cyklu życia rodziny na podjęcie decyzji o zmianie miejsca zamieszkania (rys. 3).

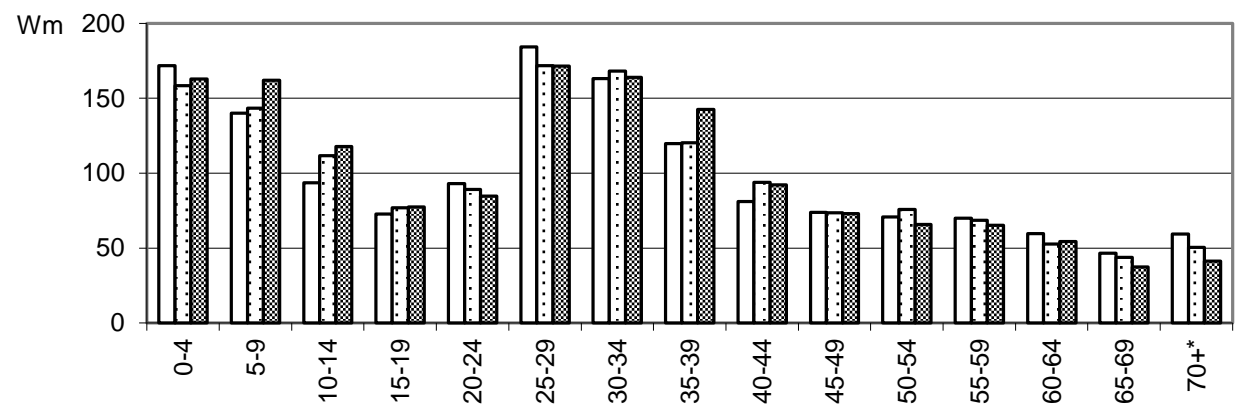

口2003 \$2004 ஐ2005

Rys. 3. Względna mobilność migracyjna w Toruniu w 2003, 2004 i 2005 r.

(według wieku)

Źródło: oprac. własne na podstawie niepublikowanych danych UM w Toruniu

Miejsce zamieszkania $\mathrm{w}$ granicach administracyjnych miasta Torunia zmieniały przede wszystkim osoby dobrze wykształcone. Największą część dorosłych migrantów stanowiły osoby z wykształceniem policealnym i średnim oraz wyższym. Analiza przeprowadzona dla lat 2003-2005 wykazała, że ich udział w strukturze wykształcenia osób pełnoletnich wyniósł odpowiednio $40,03 \%$ oraz $25,14 \%$. Odsetki osób posiadających niższe cenzusy wykształcenia były mniejsze i wyniosły: 19,60\% (zawodowe), 8,52\% (podstawowe), $0,28 \%$ (niepełne podstawowe).

$\mathrm{Z}$ uwagi na fakt, iż dane w zakresie wykształcenia mieszkańców Torunia Główny Urząd Statystyczny publikuje jedynie w oparciu o informacje pochodzące z Narodowego Spisu Powszechnego, wskaźnik względnej mobilności obliczono tylko dla roku 2003. Największą względną mobilność migracyjną posiadały osoby $\mathrm{z}$ wykształceniem wyższym $\left(\mathrm{W}_{\mathrm{m}}=156,85\right)$. Migranci z wykształceniem policealnym i średnim posiadali mobilność zbliżoną do normalnej $\left(\mathrm{W}_{\mathrm{m}}=97,06\right)$. Z kolei w grupie osób słabiej wykształconych wartość 
obliczonego wskaźnika była dużo niższa (zawodowe $\mathrm{W}_{\mathrm{m}}=85,83$; podstawowe $\mathrm{W}_{\mathrm{m}}=69,46$; niepełne podstawowe $\mathrm{W}_{\mathrm{m}}=14,19$ ). Uzyskane wyniki dowodzą, iż najwięcej realnych możliwości zmiany miejsca zamieszkania mają osoby najlepiej wykształcone. Na ogół uzyskują one wyższe zarobki, a zgromadzony kapitał umożliwia realizację potrzeb w zakresie dążeń do posiadania odpowiedniego lokalu mieszkaniowego w najbardziej preferowanej części miasta.

\subsection{MIGRACJE W UKLADZIE STREF KONCENTRYCZNYCH}

W celu uchwycenia bardziej ogólnych prawidłowości w migracjach wewnątrzmiejskich ludności Torunia przeprowadzono analizę zmian miejsca zamieszkania w układzie trzech stref koncentrycznych, tj. centralnej (obszar do $1,5 \mathrm{~km}$ od historycznego centrum miasta - Starówki), przejściowej (obszar od $1,5 \mathrm{~km}$ do 3,5 km od Starówki) oraz peryferyjnej (pozostała część miasta). $\mathrm{Z}$ uwagi na fakt, iż strefa peryferyjna obejmuje również obszar największego kompleksu zabudowy wielorodzinnej, zwanego dalej wielkim zespołem mieszkaniowym (WZM), zdecydowano o jego wydzieleniu.

W latach 2003-2005 w migracjach międzystrefowych uczestniczyło 9715 osób (tab. 1). Najwięcej osób migrowało „z” i „do” strefy przejściowej. Wielkość napływu i odpływy w tym przypadku były zbliżone i wyniosły ok. 3,5 tys. Poza strefą przejściową, znaczną liczbę nowych mieszkańców zyskała strefa peryferyjna (ok. 2,8 tys.), zaś wysokie wartości odpływu odnotowano w obrębie WZM (ponad 2,7 tys.), jak również w strefie centralnej (ponad 2,5 tys.) (rys. 4). Uzyskane salda migracji dowodzą, że zarówno strefa centralna, jak i WZM tracą ludność na skutek migracji międzystrefowych. Większe straty ludnościowe zarejestrowano w obrębie WZM (nieco ponad 1,1 tys.), niższe w strefie centralnej (ok. 0,9 tys.). Wysoki przyrost ludności z tytułu migracji międzystrefowych odnotowano natomiast w strefie peryferyjnej (ponad 1,9 tys.), znacznie niższy w strefie przejściowej (ok. 0,1 tys.).

W natężeniu ${ }^{6}$ migracji międzystrefowych zarejestrowanych w latach 20032005 uwagę zwraca bardzo wysoki współczynnik napływu do strefy peryferyjnej $(37,94 \%$ o) oraz niski do WZM $(9,87 \%$ ). Natężenie odpływu z poszczególnych stref było bardziej równomierne. Najwyższe odnotowano w strefie centralnej $(21,76 \%)$, dość wysokie w strefie WZM (16,62\%o), zaś w pozostałych strefach było ono już znacznie niższe i wyniosło odpowiednio $12,97 \%$ i $12,04 \%$ dla strefy przejściowej i peryferyjnej.

Poszerzenie analiz w zakresie migracji międzystrefowych o kierunki przemieszczeń dowodzi jednej $\mathrm{z}$ najczęściej wykrywanych regularności w migracjach wewnątrzmiejskich, tj. przemieszczenia się ludności od centrum

\footnotetext{
${ }^{6}$ Podane zostały wartości średnioroczne.
} 
miasta w kierunku przedmieść i obszarów podmiejskich (rys. 4). W przypadku Torunia proces dekoncentracji osłabiają jednak liczne migracje w obrębie tych samych stref (tab. 1). Najwyższe wartości rejestrowane są w rejonie przejściowym, gdzie blisko $60 \%$ osób zmieniających miejsce zamieszkania podejmuje decyzje o pozostaniu w dotychczas zajmowanej strefie. Wysoki udział migrantów, których zmiana miejsca zamieszkania nie wiąże się z przekroczeniem granicy danego regionu cechuje również strefę peryferyjną $(47,89 \%)$ oraz WZM $(46,27 \%)$.

Tabela 1

Wszystkie zmiany miejsca zamieszkania ludności Torunia w latach 2003-2005

(według stref koncentrycznych)

\begin{tabular}{|c|c|c|c|c|c|c|c|}
\hline \multirow[b]{2}{*}{ Odpływ } & \multicolumn{4}{|c|}{ Napływ } & \multirow[b]{2}{*}{$\begin{array}{c}\text { Odpływ } \\
\text { razem }\end{array}$} & \multirow{2}{*}{\multicolumn{2}{|c|}{$\begin{array}{l}\text { Odpływ do } \\
\text { innych }\end{array}$}} \\
\hline & centralna & $\begin{array}{l}\text { przejś- } \\
\text { ciowa }\end{array}$ & $\begin{array}{l}\text { peryfe- } \\
\text { ryjna }\end{array}$ & WZM & & & \\
\hline \multicolumn{8}{|c|}{ lata 2003-2005 } \\
\hline Strefa & osoby & osoby & osoby & osoby & osoby & osoby & $\%$ \\
\hline Centralna & 1216 & 1480 & 587 & 509 & 3792 & 2576 & 67,93 \\
\hline Przejściowa & 1066 & 4740 & 1418 & 959 & 8183 & 3443 & 42,08 \\
\hline Peryferyjna & 159 & 553 & 829 & 190 & 1731 & 902 & 52,11 \\
\hline WZM & 440 & 1528 & 826 & 2406 & 5200 & 2794 & 53,73 \\
\hline $\begin{array}{c}\text { Napływ } \\
\text { razem }\end{array}$ & 2881 & 8301 & 3660 & 4064 & 18906 & $\mathrm{x}$ & $\mathrm{x}$ \\
\hline $\begin{array}{l}\text { Napływ } \\
\text { z innych }\end{array}$ & 1665 & 3561 & 2831 & 1658 & $x$ & $\mathrm{x}$ & $x$ \\
\hline$\%$ & 57,79 & 42,90 & 77,35 & 40,80 & $\mathrm{x}$ & $\mathrm{x}$ & $\mathrm{x}$ \\
\hline
\end{tabular}

Źródło: oprac. własne na podstawie niepublikowanych danych UM w Toruniu.

Warto przy tej okazji zwrócić uwagę, iż do WZM kierują się przede wszystkim mieszkańcy strefy przejściowej. Dodając, iż w ten rejon w latach 2003-2005 przybyły 1463 osoby pochodzące spoza granic Torunia tj. ok. 24\% wszystkich imigrantów (Radwańska 2010) można stwierdzić, iż stare osiedla bloków podlegają wymianie migracyjnej, w której uczestniczą przede wszystkim mieszkańcy wielkiego miasta. Takich samych wniosków dostarczają analizy dotyczące Krakowa przeprowadzone przez A. Zborowskiego (2005). Dowodzi to odmiennych od spotykanych na zachodzie mechanizmów sukcesji migracyjnej w wielkich ośrodkach. Tym samym nie ma podstaw do twierdzenia wskazującego na potwierdzenie zachodniej drogi rozwoju społecznego, przez osiedla bloków w miastach Polski i będące jej konsekwencją szybkie procesy degradacji społecznej (ibid.). 

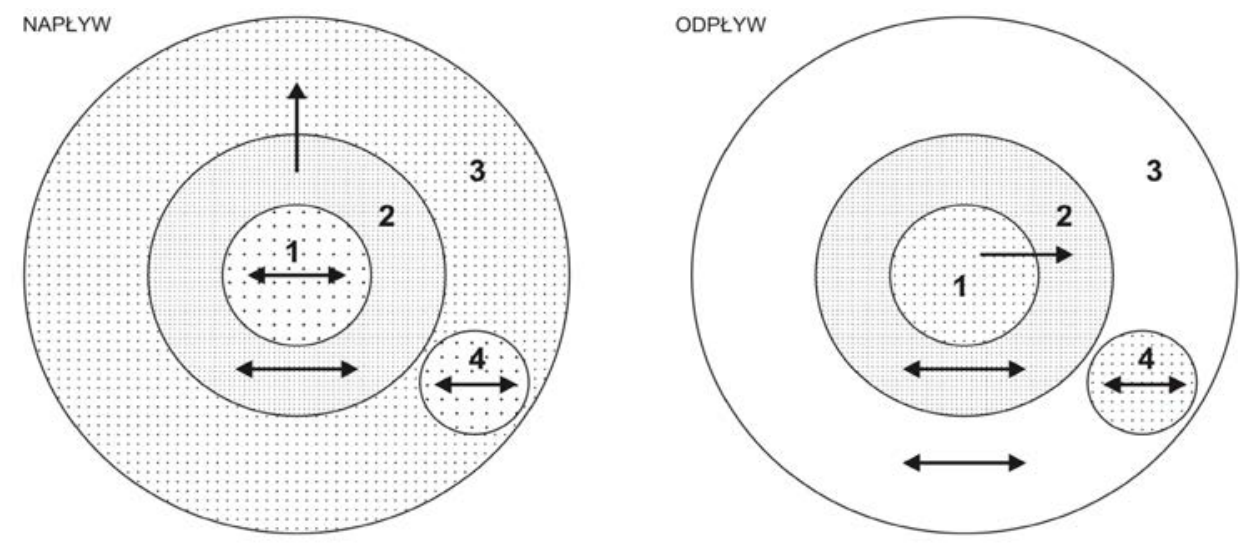

napływ / odpływ międzystrefowy
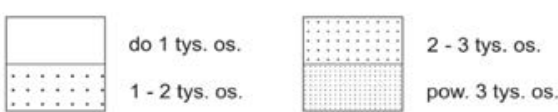

1- strefa centralna 3- strefa peryferyjna

2- strefa przejściowa 4- WZM

pow. 3 tys. os.

dominujący kierunek przemieszczeń

Rys. 4. Dominujące kierunki napływu i odpływu ludności w migracjach wewnątrzmiejskich w latach 2003-2005 (według stref koncentrycznych)

Źródło: oprac. własne na podstawie niepublikowanych danych UM w Toruniu

\subsection{Podsumowanie}

Przeprowadzone badania pozwalają na sformułowanie kilku następujących wniosków ogólnych:

1. Toruń cechuje wysokie natężenie zjawiska ruchliwości mieszkaniowej rzędu 30\%o. Fakt ten świadczy, z jednej strony o dość dobrej kondycji ekonomicznej gospodarstw domowych badanego miasta, z drugiej zaś o sprawnie funkcjonującym rynku mieszkaniowym (pierwotnym i wtórnym). Należy w tym momencie nadmienić, iż w strefie bliskiego zaplecza centrum przestrzeń mieszkaniowa została intensywnie dogęszczona. Ponadto „nowe” budownictwo mieszkaniowe „wkroczyło" na tereny uwolnione wewnątrz miasta (m.in. tereny powojskowe) oraz na jego obrzeża. Rejestrowana na przełomie XX i XXI w. przewaga podaży nad popytem sprawiała jednak, iż oferenci mieszkań dostosowują propozycje do możliwości finansowych konsumentów oraz ich preferencji. Przejawia się to m.in. w zmniejszeniu powierzchni użytkowej większości oferowanych lokali oraz pojawieniu się osiedli typu gated communites (Gierańczyk 2006).

2. Charakter i wielkość salda migracji wewnątrzmiejskich zmienia się wraz z odległością od historycznego centrum miasta. Ubytek migracyjny ludności jest charakterystyczny dla rejonu centralnego obejmującego m.in. Starówkę oraz dla 
największego kompleksu zabudowy wielorodzinnej założonego w połowie lat 70. XX w., do budowy którego użyto materiałów prefabrykowanych tzw. wielkiej płyty. W dalszej części miasta rejestrowany jest przyrost migracyjny. Dodać należy, iż największe natężenie zjawiska jest charakterystyczne dla strefy peryferyjnej, gdzie zabudowie jednorodzinnej towarzyszą nieliczne enklawy nowych budynków wielorodzinnych.

Ubytek migracyjny w centralnym rejonie miasta w znacznym stopniu łączyć należy z wypieraniem funkcji mieszkaniowej przez usługową. Z przeprowadzonych przez R. Jaroszewską-Brudnicką (2008) badań wynika, iż w dobie narastającej konkurencji o najatrakcyjniejsze obszary w mieście, tereny śródmiejskie Torunia zyskują nowe znaczenie, przede wszystkim jako miejsce lokalizacji różnego rodzaju placówek usługowych. Wyrazem tego jest z jednej strony rosnąca liczba placówek powstających głównie w piwnicach bądź na wyższych piętrach kamienic zlokalizowanych wzdłuż głównych osi handlowo-usługowych, z drugiej ,,aktywizacja funkcjonalna” obszarów, które do niedawna pełniły przede wszystkim funkcje mieszkaniowe (Jaroszewska-Brudnicka 2008).

3. Migracje wewnątrzmiejskie ludności Torunia mają charakter selektywny, co z demograficznego punktu widzenia skutkuje zróżnicowaniem rozkładu płci i wieku, zaś na płaszczyźnie społecznej znajduje swe odzwierciedlenie w strukturze wykształcenia migrantów. Decyzję o zmianie miejsca zamieszkania podejmują najczęściej osoby młode, zazwyczaj dobrze wykształcone mające najczęściej 25-29 lat. Z ich wysokimi udziałami koresponduje znaczny odsetek dzieci z najmłodszych grup wiekowych. Zachowując pewien stopień ostrożności można dwie wskazane grupy migrantów traktować łącznie jako młode, rozwojowe rodziny. Przyjęcie takiego toku rozumowania pozwala szukać wyjaśnienia przyczyn migracji w cyklu życiowym jednostek oraz całych rodzin. O słuszności przyjęcia takiej tezy świadczy również spadek natężenia przemieszczeń osób po 30 roku życia, ożywienie ruchów migracyjnych osób mających 45-49 lat oraz niewielka liczba migrujących emerytów.

4. Empiryczny profil wieku osób, które zmieniły miejsce zamieszkania w Toruniu w latach 2003-2005 nawiązuje do modelowego rozkładu migracji według wieku przedstawionego przez A. Rogersa (1980). Podobieństwo występuje w układzie trzech kolejnych ,wzniesień”. Zaznaczyć jednak należy, iż ostatnie ożywienie ruchów migracyjnych ma miejsce przed wkroczeniem w wiek emerytalny i jest ono niższe niż w rozkładzie wzorcowym. Wyjaśnienia tej sytuacji upatrywać należy w stabilizacji finansowej osób po 45 roku życia (tj. znajdujących się w dalszej fazie rozwoju rodziny). Poprawa sytuacji ekonomicznej będąca skutkiem przechodzenia przez kolejne szczeble kariery zawodowej stwarza możliwość realizacji ciągłych dążeń w zakresie zajęcia optymalnego lokalu. 
Reasumując należy stwierdzić, iż wysokie ceny kupna mieszkania ograniczają, lecz nie eliminują realizacji dążeń w zakresie posiadania odpowiedniego lokalu w preferowanej części miasta. Koszty związane ze zmianą miejsca zamieszkania $\mathrm{w}$ wielu przypadkach decydują jednak o tym, iż w migracjach wewnątrzmiejskich uczestniczą przede wszystkim osoby mające dobrą sytuację finansową. Z kolei następstwem przemieszczeń są procesy prowadzące do przestrzennego grupowania mieszkańców zależnie od poziomu dochodów i statusu społecznego. Tytułem zakończenia warto zatem przytoczyć słowa Zygmunta Baumana (2000): „Mobilność okazuje się najwyżej cenioną i pożądaną wartością, a swoboda poruszania się - ten nierówno dzielony towar szybko staje się głównym czynnikiem kształtującym społeczne podziały”.

\section{LITERATURA}

Adams J.S., 1969, Directional bias in intraurban migration, “Economic Geography”, no 45,4 , s. $302-323$.

Basista A., 1999, Dlaczego czeka nas odnowa osiedli zwanych blokowiskami [w:] Włodarczyk J.A. (kom. nauk.), Współczesna architektura mieszkaniowa: II Konferencja Naukowa Mieszkanie XXI w., Augustów 26-28 maja 1999, Wydział Architektury Politechniki Białostockiej, ZO SARP, Wydawnictwo Fundacja Ekonomistów Środowiska i Zasobów Naturalnych, Białystok, s. 196-202.

Bauman Z., 2000, Globalizacja. I co z tego dla ludzi wynika?, PIW, Warszawa.

Clark W.A.V., 1981, Residential mobility and behavioral geography: parallelism or interdependence? [w:] Cox K.R., Golledge R.G. (red.), Behavioral problems in geography revisited, Methuen, London, s. 182-205; [w:] PZLG, 1986, Geografia behawioralna, z. 3-4, s. 67-88.

Donzeau N., Pan Ké Shon J.-L., 2009, Residential Mobility Trends in France 19732006. New Estimates, „Population”, 64, 4, s. 687-703.

Dzieciuchowicz J., 1995, Determinanty demograficzne i społeczno-ekonomiczne redystrybucji przestrzennej ludności aglomeracji miejskich. Przykład aglomeracji łódzkiej, Wydawnictwo UŁ, Łódź.

Gawryszewski A., 1989, Przestrzenna ruchliwość ludności Polski 1952-1985, Prace habilitacyjne PAN, IGiPZ, Zakład Narodowy im. Ossolińskich, Wrocław.

Gierańczyk W., 2006, Nowe budownictwo mieszkaniowe w przestrzeni Torunia (19882004) [w:] Komornicki T., Podgórski Z. (red.), Idee i praktyczny uniwersalizm geografii. Geografia społeczno-ekonomiczna, Dydaktyka, „Dokumentacja Geograficzna”, nr 33, IGiPZ PAN, Warszawa, s. 65-69.

Gustafson P., 2009, Mobility and Territorial Belonging, "Environment \& Behaviour”, no 41, 4, s. 490-508.

Jagielski A., 1977, Geografia ludności, PWN, Warszawa. 
Jałowiecki B., 1992, Gra o miasto w sytuacji transformacji ustroju [w:] Jałowiecki B. (red.), Gra o miasto, „Biuletyn KPZK PAN”, z. 157, Warszawa, s. 7-14.

Jałowiecki B., Szczepański M.S., 2002, Miasto i przestrzeń $w$ perspektywie socjologicznej, Scholar, Warszawa.

Jaroszewska-Brudnicka R., 2008, Ewolucja funkcji usługowej w obrębie historycznego centrum miasta. Przykład Torunia [w:] Słodczyk J., Szafranek E., (red.), Mechanizmy i uwarunkowania budowania konkurencyjności miast, UO, Opole, s.191-202.

Kaczmarek J., Liszewski S., 1991, Ruchliwość przestrzenna mieszkańców Lodzi w świetle analizy zmiany miejsc zamieszkania, „Acta Universitatis Lodziensis”, Folia Geographica, no 13, Wydawnictwo UŁ, Łódź, s. 41-53.

Knox P.L., Pinch S., 2000, Urban Social Geography, Pearson Education Limited, Edinburgh Gate, Harlow.

Kozieł R., 1984, Metodologiczne problemy migracji wewnatrzmiejskich [w:] Strzelecki Z. (red.), Teoretyczne $i$ metodologiczne problemy badania różnych form migracji ludności Polski, Zakład Demografii Społeczno-Ekonomicznej Szkoły Głównej Planowania i Statystyki w Warszawie, Koszaliński Ośrodek Naukowo-Badawczy, Koszalin, s. 224-241.

Kozieł R., 1987, Międzyosiedlowe migracje ludności we Wrocławiu w 1979 r. [w:] Migracje regionalne - problemy teoretyczne i metodologiczne, „Acta Universitatis Wratislaviensis”, no 795, „Studia Geograficzne” XLII, Wydawnictwo Politechniki Wrocławskiej, Wrocław, s. 109-120.

Kozieł R., 1989, Wewnątrzmiejskie migracje ludności we Wrocławiu w 1979 roku, „Acta Universitatis Wratislaviensis”, no 1006, „Studia Geograficzne”, XLVI, Wydawnictwo UWr., Wrocław.

Kozieł R., 1996, Czasoprzestrzenna zmienność migracji wewnatrzmiejskich we Wrocławiu, „Acta Universitatis Wratislaviensis”, no 1904, Prace Instytutu Geograficznego, Seria B, Geografia Społeczna i Ekonomiczna, t. XIV, PWN, Warszawa-Wrocław, s. $45-52$.

Kozieł R., 1998, Migracje do budownictwa plombowego we Wrocławiu [w:] Ciok S., Łoboda J. (red.), Przekształcenia regionalnych struktur funkcjonalno-przestrzennych, „Studia Geograficzne”, LXIX, Wydawnictwo UWr., Wrocław, s. 213-218.

Lord S., Joerin F., Theriault M., 2009, La mobilité quotidienne de banlieusards vieillissants et âgés: Déplacements, aspirations et significations de la mobilité, "Canadian Geographer”, 53, 3, s. 357-375.

Maik W., 1997, Podstawy geografii miast, wyd. 2, UMK, Skrypty i teksty pomocnicze, Toruń.

Marcinowicz D., 2000, Zmienność migracji wewnątrzmiejskich w Poznaniu w latach 1989-1997 [w:] Słodczyk J. (red.), Społeczne, gospodarcze i przestrzenne przeobrażenie miast, Wydawnictwo UO, Opole, s. 115-127.

Michalski W., Szafrańska E., 2000, Wewnątrzmiejskie migracje stałe mieszkańców Łodzi w 1997 roku [w:] Szymańska D. (red.), Procesy i formy ruchliwości przestrzennej ludności w okresie przemian ustrojowych, UMK, Toruń, s. 201-215.

Morgan B.S., 1976, The Bases of Family Status Segregation, “Transactions”, Institute of British Geographers, 1, 86. 
Pawłowska K., 1996, Idea swojskości w urbanistyce i architekturze miejskiej, PK, Seria: Architektura, Monografia, 203, Karków.

Potrykowska A., 1996, A study of intra-urban migration: the case of Warsaw [w:] Spatial Analysis of Biodemographic Data, Paris, INED.

Potrykowska A., 2002, Zróżnicowanie przestrzenne migracji wewnętrznych $w$ regionie miejskim Warszawy [w:] Warszawa jako przedmiot badań $w$ geografii społeczno-ekonomicznej, „Prace Geograficzne”, nr 184, PWN, Warszawa, s. 103-114.

Potrykowska A., Śleszyński P., 1999, Migracje wewnętrzne $w$ Warszawie $i$ województwie warszawskim w okresie transformacji, Atlas Warszawy, 7, IGiPZ PAN, Warszawa.

Pritchard R.M., 1976, Housing and the Spatial Structure of the City, University Press, Cambridge.

Radwańska M., 2010, Wewnątrzmiejskie migracje stałe jako czynnik kształtujacy struktury społeczno-demograficzne wielkiego zespolu mieszkaniowego Torunia [w:] Jażdżewska I. (red.), Osiedla blokowe w strukturze przestrzennej miast, „XXIII Konwersatorium Wiedzy i Mieście”, Wydawnictwo UŁ, Łódź, s. 237-249.

Radwańska M., 2011, Związki człowieka z miejscem na przykładzie analizy migracji wewnątrzmiejskich. Przypadek Torunia [w:] Marciniak K., Sikora K., Sokołowski D. (red.), Koncepcje i problemy badawcze geografii, WSG, Bydgoszcz, s. 299-309.

Rogers A., 1980, Migration patterns and population redistribution, Laxenburg, IIASA.

Rossi P.H., 1955, Why Families Move, Free Press, Glencoe, III.

Sagan I., 2000a, Miasto. Scena konfliktów i wspótpracy. Rozwój miasta $w$ świetle koncepcji reżimu miejskiego, Wydawnictwo UG, Gdańsk.

Sagan I., 2000b, Społeczny i rynkowy wymiar miejsc $w$ mieście socjalistycznym i postsocjalistycznym [w:] Jażdżewska I., (red.), Miasto postsocjalistyczne. Organizacja przestrzeni miejskiej i jej przemiany, „XIII Konwersatorium Wiedzy o Mieście”, ŁTN, Łódź, s. 67-71.

Simmons J.W., 1968, Changing residence in the city: a review of intra-urban mobility, “Geographical Review”, no 58, s. 622-651.

Słodczyk J., 2003, Przestrzeń miasta i jej przeobrażenia, „Studia i Monografie”, nr 298, Wydawnictwo UO, Opole.

Stachura E., 2009, Determinanty zmian w architekturze mieszkaniowej okresu transformacji w Polsce, Wydawnictwo PŚ, Gliwice.

Strzelecki Z., 1989, Cykl życia rodziny a migracje, „Monografie i Opracowania ISiD SGPiS”, nr 296, 5, Warszawa.

Sykora L., 1996, Economic and social restructuring and gentrification in Prague, “Acta Facultatis Naturalium Universitatis Comeniane”, Geographica, no 37, s. 70-81.

Szajnowska-Wysocka A., 1999, Zachowania przestrzenne ludności konurbacji górnośląskiej. Synteza badawcza, Wydawnictwo UŚ, Katowice.

Walmsley D.J., Lewis G.J., 1997, Geografia człowieka. Podejścia behawioralne, PWN, Warszawa.

Węcławowicz G., 2007, Geografia społeczna miast. Uwarunkowania społeczno-przestrzenne, PWN, Warszawa. 
Więcław-Michniewska J., 2006, Krakowskie suburbia i ich społeczność, Instytut Geografii i Gospodarki Przestrzennej, UJ, Kraków.

Zborowski A., 1996, Migracje $w$ Krakowie $w$ kontekście cyklu życia człowieka [w:] Runge J. (red.), Problemy społeczne rozwoju regionalnego, Wydawnictwo UŚ, Sosnowiec, s. 83-92.

Zborowski A., 2005, Przemiany struktury społeczno-przestrzennej regionu miejskiego w okresie realnego socjalizmu i transformacji ustrojowej (na przykładzie Krakowa), Instytut Geografii i Gospodarki Przestrzennej UJ, Kraków.

\section{Abstract}

\section{INTRA-URBAN MOBILITY OF THE POPULATION IN CITIES AT THE BEGINNING OF XXI CENTURY. STUDY BASED ON TORUŃ AS AN EXAMPLE}

The subject of this study is the intercity migration of people which took place in Torun in 2003-2005. The most important conclusions from the research can be presented synthetically as follows:

1. Studies show high intra-urban mobility of the population of Torun, the order of $30 \%$. This fact proves the one hand the relatively good economic condition of households in Torun, on the other hand, a well-functioning housing market.

2. Intra-urban migrations of Torun citizens are of a selective character. From the demographical point of view, their effects are diversity in sex and age distribution, but in the social field it is reflected in the structure of the education of migrants. The living place is first of all changed by citizens who are from 25 to 29 years old, and well-educated people. Women are dominating in the structure of sex. High mobility of young people is reflected in high number of migrating children. The lack of data concidering the migration of whole families makes it impossible to draw straightforward conclusions. Making careful conclusions it may be defined that above two groups are young, growing families. Applying this way of reasoning confirms the existence of the influence of the life cycle on taking decisions considering living place changes.

3. Empirical profiles of the age of people who changed their living place in the researched period refer to the model distribution of migration presented by A. Rogers (1980). Similarity exists in the configuration of three following "rises". However, it should be underlined that the latest increase in migrations takes place before a retirement age and it is lower that in the model distribution. This situation should be explained as the financial stabilization of people who are from 45 to 59 and from 50 to 54 years old. The improvement of the career and economical situation makes it possible to realize plans considering living in the proper place.

4. The character and size of the intra-urban migration balance change along with the increase in the distance from the city centre. Migrational decrease is characteristic for central regions of Torun which cover the oldest medieval architecture and for the biggest number of blocks of flats (WZM). In the further part of the city, there is a registered 
increase in people migrations. It should be mentioned that the most essential intensity of the phenomenon was registered in units situated along the administrational borders of Torun with single-family houses together with new groups of blocks of flats.

Dr Monika Radwańska

Zakład Geografii Społecznej i Turystyki Wydział Nauk o Ziemi, Uniwersytet Mikołaja Kopernika 